\title{
Long Aboral Projections of Dogiel Type II, AH Neurons within the Myenteric Plexus of the Guinea Pig Small Intestine
}

\author{
S. J. H. Brookes, Z.-M. Song, G. A. Ramsay, and M. Costa \\ Department of Human Physiology and Centre for Neuroscience, The Flinders University of South Australia, \\ Adelaide, 5001, South Australia
}

\begin{abstract}
Enteric AH neurons, with multipolar Dogiel type II morphology, project around the circumference of the intestine to myenteric ganglia, the submucosa and mucosa. Using retrograde labeling in vitro, intracellular recording, dye filling and immunohistochemistry, the projections of these neurons along the intestine were studied. When the retrograde tracer, Dil, was applied to the myenteric plexus, labeled nerve cell bodies were located up to $111 \mathrm{~mm}$ orally but only $13 \mathrm{~mm}$ aborally, demonstrating a marked difference in the lengths of projections up and down the small intestine. Of labeled nerve cell bodies located 2-110 $\mathrm{mm}$ orally, $43 \%$ had Dogiel type II morphology and of these, $70 \%$ were immunoreactive for calbindin, a calcium binding protein exclusive to Dogiel type II neurons. Intracellular filling with neurobiotin revealed several long circumferentially directed nerve fibers and short, filamentous dendrites; thus these were "dendritic" Dogiel type II neurons. This class accounts for approximately $3-4 \%$ of all myenteric neurons, and about $10 \%$ of all Dogiel type II neurons. Intracellular recordings revealed $\mathrm{AH}$ cell characteristics, with long afterhyperpolarizations following their action potentials, pronounced slow excitatory synaptic inputs and a lack of fast excitatory synaptic inputs. Antidromic action potentials could be evoked from the Dil application site in some cells, confirming their aboral projection. This is the first account of a major aboral projection of AH/Dogiel type II neurons and suggests an important role in aborally directed reflexes in the intestine.
\end{abstract}

[Key words: myenteric plexus, calbindin, $A H$ cells, intestine, motility, enteric nervous system]

The enteric nervous system contains sensory neurons, interneurons and motor neurons which are organized into neuronal circuits within the wall of the gastrointestinal tract. These circuits play an important role in coordinating the movements of the stomach and intestines which are essential for normal digestion. Enteric neurons are organized into two ganglionated plexuses; the myenteric plexus which lies between the longitudinal and circular smooth muscle layers and the submucous plexus which lies within the submucosa. Intensive research has been carried out over the last two decades to identify the neuronal mecha-

\footnotetext{
Received July 18. 1994: revised Dec. 27, 1994; accepted Dec. 30, 1994.

This study was supported by NH and MRC of Australia. S.J.H. Brookes is a Senior Research Fellow of the Gastroenterological Society of Australia

Correspondence should be addressed to Dr. S. J. H. Brookes, Department of Human Physiology. The Flinders University of South Australia, GPO Box 2100 , Adelaide, SA 5001, Australia.

Copyright (O) 1995 Socicty for Neuroscience $0270-6474 / 95 / 154013-10 \$ 05.00 / 0$
}

nisms that underlie the control of gastrointestinal motility. One particular class of neurons in the myenteric plexus, the $\mathrm{AH}$ neurons, has been the subject of many electrophysiological and morphological studies. A variety of characteristics can be used to identify AH cells; chief among them is the long afterhyperpolarization that follows their action potentials (see Bornstein et al., 1994; Wood, 1994, for reviews). Many AH cells have been demonstrated to have Dogiel type II morphological features (Bornstein et al., 1984; Erde et al., 1985; Katayama et al., 1986; Iycr ct al., 1988; Hendriks et al., 1990; Bornstein et al., 1991) with large round or oval cell bodies and several long, tapering processes that run circumferentially out of the ganglion of origin and which give rise to varicose endings in surrounding myenteric ganglia (Bornstein et al., 1991). A subtype of Dogiel type II neuron, with multiple, short dendritic processes, has also been described (Stach, 1989) and shown to have a different pattern of local projections to other Dogiel type II neurons (Bornstein et al., 1991). Many Dogiel type II neurons are immunoreactive for ChAT (Steele et al., 1991), substance P or a related tachykinin (Song et al., 1991), neuromedin U (Furness et al., 1989) and about $80-85 \%$ are immunoreactive for the calcium binding protein calbindin (Furness et al., 1988; Iyer et al., 1988; Furness et al., 1990). The axons of Dogiel type II neurons run predominantly in the circumferential direction within the myenteric plexus (Furness et al., 1990; Hendriks et al., 1990) where they branch extensively (Bornstein et al., 1991), and send branches to the submucosa and mucosa (Furness et al., 1990; Song et al., 1991).

From preliminary studies using retrograde labeling in vitro, some Dogiel type II neurons appeared to have long projections running longitudinally for many millimeters within the myenteric plexus of the guinea pig small intestine that have not been described previously. Here we demonstrate that the "dendritic" type of Dogiel type II neuron have typical AH cell electrophysiological characteristics and form the largest single source of aborally directed nerve fibers within the enteric nervous system.

\section{Materials and Methods}

Tissue preparation for organotypic culture. The details of the techniques have been previously described (Brookes and Costa 1990; Song et al., 1991, 1992). In brief, adult male and female guinea pigs (200$350 \mathrm{gm}$ ) were stunned and killed by exsanguination and specimens of distal, but not terminal small intestinc, were removed under aseptic conditions. They were then placed immediately into sterile Krebs' solution (composition, in mM: $\mathrm{NaCl}, 117 ; \mathrm{KCl}, 5 ; \mathrm{MgSO}_{4}, 1.2 ; \mathrm{NaHCO}_{3}$, 25; $\mathrm{NaH}_{2} \mathrm{PO}_{4}, 1.2 ; \mathrm{CaCl}_{2}, 2.5 ;$ glucose, 10 ; bubbled with $95 \% \mathrm{O}_{2} / 5 \%$ $\mathrm{CO}_{2}, \mathrm{pH} 7.4$, containing $1 \mu \mathrm{M}$ nicardipine). The lumen was flushed free of intestinal contents and the piece of intestine was opened along the mesenteric border, pinned out with the mucosa up, in a Sylgard-lined petri dish and rinsed repeatedly with fresh sterile Krebs' solution. The 
mucosa and submucosa were then removed by dissection from the entire preparation and a thin strip of circular muscle was peeled away, within $20 \mathrm{~mm}$ of the aboral end of the tissue, to expose the myenteric plexus.

Throughout this study, the dye, Dil (1,1'-didodecyl-3,3,3',3'-tetramethyl indocarbocyanine perchlorate; Molecular Probes, Eugene, OR) was used for retrograde labeling. To study projections of Dogiel type II neurons within the myenteric plexus, DiI was evaporated from ethanolic solution at room temperature, onto small glass beads $(100-200 \mu \mathrm{m}$ in diameter, Sigma Chemicals), which were then pressed gently onto the surface of one or more exposed internodal strands of the myenteric plexus (in the area where circular muscle was removed) so that they adhered to the tissue.

Organotypic culture. After a 10 min delay, to allow the Dil-coated bead to adhere, the tissue was washed repeatedly with sterile Krebs' solution then covered in $20 \mathrm{ml}$ of sterile culture medium (DMF/F 12, Sigma Chemicals) supplemented with $10 \%$ heat-inactivated fetal bovine serum, penicillin $100 \mathrm{IU} / \mathrm{ml}$, streptomycin $100 \mu \mathrm{g} / \mathrm{ml}$, fungizone 2.5 $\mu \mathrm{g} / \mathrm{ml}$, gentamicin $20 \mu \mathrm{g} / \mathrm{ml}$ (Cytosystems, N.S.W., Australia) and adjusted to $\mathrm{pH} 7.4$. The $9 \mathrm{~cm}$ diameter petri dish was then placed in a humidified incubator $\left(37^{\circ} \mathrm{C}\right.$, equilibrated with $5 \% \mathrm{CO}_{2}$ in air) and agitated. The culture medium was changed daily. The tissues were cultured for $72 \mathrm{hr}$ to allow the optimal retrograde transport of Dil from the nerve terminals to their cell bodies of origin.

Immunohistochemistry. Organ cultured tissue was fixed for $18-24 \mathrm{hr}$ at $4^{\circ} \mathrm{C}$ in modified Zamboni's fixative $(15 \%$ saturated picric acid and $2 \%$ formaldehyde in phosphate buffer $0.1 \mathrm{M}$; $\mathrm{pH} 7.0$ ). It was then washed repeatedly in phosphate buffered saline (PBS: $0.15 \mathrm{M} \mathrm{NaCl}$ in $0.01 \mathrm{M}$ sodium phosphate, $\mathrm{pH} 7.2$ ) over a period of $3 \mathrm{hr}$ before processing for immunohistochemistry. To enhance the penetration of antisera without affecting Dil localization, tissues were cleared for 1 hour in bicarbonate-buffered glycerol $(70 \%$ glycerol in $0.5 \mathrm{M}$ sodium carbonate buffer, $\mathrm{pH}$ 8.6) prior to incubation with the primary antibodies.

Indirect immunofluorescence techniques using primary antisera combined with fluorophore-labeled secondary antibodies were used for labeling of whole-mount preparations that had previously been analyzed for the projections of different morphological classes of neurons within the myenteric plexus. Whole mounts of tissues were incubated with a monoclonal mouse anti-calbindin D-28K antisera (Celio and Norman, 1985; Song et al., 1991) diluted 1:1000 for 18-48 hr at room temperature in a humid chamber. Tissues were then rinsed in PBS and incubated with the fluorescein isothiocyanate (FITC)-conjugated goat anti-mouse IgG (Cappel Laboratories, Cochranville, USA, code 31649) at 1:160. Following a final rinse in PBS, tissues were mounted in bicarbonate-buffered glycerol.

Analysis of preparations. Whole-mount preparations up to $130 \mathrm{~mm}$ in length were analyzed to establish the distributions of nerve cell bodies in relation to the Dil application site. Specimens were viewed under a Leitz Laborlux D microscope fitted with fluorescent epiillumination using a $50 \mathrm{~W}$ high-pressure mercury lamp as a light source. Filter block N2 was used to view DiI fluorescence; filter block L3 to view FITC fluorescence and a filter block modified from an A2 filter block (with the excitation filter of an $\mathrm{H} 3$ filter used as a substitute emission filter, together with an additional $430 \mathrm{~nm}$ long pass filter) was used for AMCA fluorescence. With this combination of filter blocks, each fluorophore could be viewed independently. Kodak T-MAX 400 film rated at 800 ASA was used for black and white photography. In each preparation, the position and the chemical identity of each DiI-labeled neuron was recorded by measuring the stage position of the microscope with a high resolution ( $1 \mu \mathrm{m}$ ) computerized plotting system (Brookes et al., 1992). Data was plotted using commercial graph plotting software (SIGMAPLOT 5.1, Jandel, Corte Madera, CA). Results were obtained from three to six preparations from three to five animals for each set of experiments.

Electrophysiology. Neurons with Dogiel type 11 morphological characteristics, and projections longer than $10 \mathrm{~mm}$, were targeted for intracellular recording following retrograde labeling in organotypic culture using the methods described above. After $3 \mathrm{~d}$ in culture the circular muscle was removed from the entire preparation and the longitudinal muscle-myenteric plexus preparation was pinned flat in a recording chamber and superfused with oxygenated Krebs' solution at $33-35^{\circ} \mathrm{C}$ containing $1-2 \mu \mathrm{M}$ nicardipine and $1-2 \mu \mathrm{M}$ hyoscine hydrobromide to prevent spontaneous muscle activity. Specimens up to $35 \mathrm{~mm}$ long, with the DiI application site attached, could be accommodated in the recording chamber. With the rhodamine filter on an Olympus IMT2 inverted microscope, DiI-labeled cells were visualized in living tissue using 400 times total magnification. Microelectrodes were advanced vertically into the DiI filled cells whilst taking care to minimize the total period of illumination with excitation wavelengths for Dil.

Microelectrodes were tip-filled with either biocytin (Sigma Chemicals) or, later, with the more soluble neurobiotin (Vector Lab., Burlingame, CA) at $2-4 \% \mathrm{w} / \mathrm{v}$ in $0.5 \mathrm{M} \mathrm{KCl}$ ), back-filled with $0.5 \mathrm{M} \mathrm{KCl}$ and had resistances of 120-180 M 2 . Cells were filled with depolarizing current pulses $(0.2-0.5 \mathrm{nA}$, with a duty cycle of $50 \%)$ for $1-2$ min ai the beginning and end of each impalement. Intracellular recordings and current injection were carried out with an Axoclamp-2A amplifier (Axon Instruments, Foster City, CA) in bridge mode. Focal electrical stimulation with $0.25 \mathrm{msec}$ pulses from a Grass S88 stimulator, via a Grass SIU stimulus isolation unit, was delivered through bipolar $25 \mu \mathrm{m}$ platinum/iridium wire electrodes insulated to within $50 \mu \mathrm{m}$ of their tips. The micromanipulators for the recording and stimulating electrodes were mounted on the microscope stage. allowing the stimulating electrode to be repositioned to any point in the preparation, under visual control, whilst maintaining an intracellular impalement. Recordings were made using AXOTAPE version 1.0 (Axon Instruments, Foster City CA) data acquisition system and analyzed using AXOGRAPH 1.0 software (Axon Instruments, Foster City, CA). Electrophysiological and morphological measurements are expressed as means 1 standard errors of the means (SEMs).

Neurobiotin or biocytin-filled preparations were fixed overnight in modified Zamboni's fixative and washed repeatedly in PBS. The tissues were then cleared in glycerol, as described previously (Brookes et al., 1992; Song et al., 1992), prior to incubation with 1:50 streptavidin 7-amino-4-methylcoumarin-3-acetic acid (AMCA, Amersham, UK) for $2 \mathrm{hr}$. The preparations were then washed again in PBS and mounted in bicarbonate-buffered glycerol ( $\mathrm{pH} 8.6$ ) for analysis and photography. For immunohistochemical analysis, preparations were labeled for calbindin immunohistochemistry as described above. The presence of neurobiotin (or biocytin) labeling coinciding with $\mathrm{DiI}$ was taken as evidence that the correct cell had been impaled: recordings in which this was not the case were discarded. After analysis the impaled cells were visualized through overnight incubation in Vectastain (Vector Laboratories, Burlingame, $\mathrm{CA}$ ) followed by a $\mathrm{DAB} /$ hydrogen peroxide reaction and were drawn with a camera lucida attached to an Olympus BH2 microscope fitted with differential interference contrast optics.

\section{Results}

\section{Projection of neurons labeled from the myenteric plexus}

Application of DiI to a single internodal strand or myenteric ganglion typically labeled from 500 to 1000 neurons scattered throughout the myenteric plexus. Cells were found up to 130 $\mathrm{mm}$ oral to the DiI application site but never more than $13 \mathrm{~mm}$ aborally. The preliminary observation that many labeled nerve cell bodies located more than $2 \mathrm{~mm}$ oral to the application site appeared to have Dogiel type II morphology, in apparent contradiction to previous studies (Hendriks et al., 1990; Bornstein et al., 1991), led to this investigation. In five preparations from five animals a single DiI-coated glass bead was applied to the intersection of an internodal strand with a myenteric ganglion. A typical example of the resulting labeling is shown in Figure 1. A significant proportion of Dil-labeled Dogiel type II neurons were located circumferential to the application site, within $2 \mathrm{~mm}$ oral or aboral to the application site. Dogiel type II neurons constituted on average $39.3 \%$ of these locally projecting neurons (327 neurons of 832 from five preparations in five animals). In addition many DiI-labeled Dogiel type II neurons were located oral to the application site, but very few were found more than $2 \mathrm{~mm}$ aboral to the application site. In fact, Dogiel type II neurons comprised $43.2 \%$ of all neurons with descending projections longer than $2 \mathrm{~mm}$ ( 1212 out of 2807 neurons, $n=5$ ). The majority of Dogiel type II neurons located either oral $(69.9 \%)$ or circumferential to the application site $(80.1 \%)$ were immunoreactive for the calcium binding protein calbindin (Fig. 2). The distributions of Dogiel type II neurons labeled from the myenteric plexus are shown in Figure 3.

To assess the proportions of Dogiel type II neurons with long 


\section{Dogiel type II}

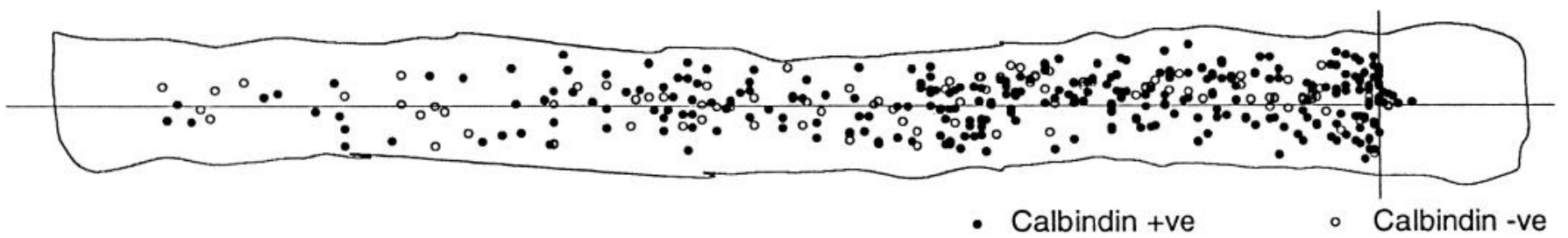

Other cell types

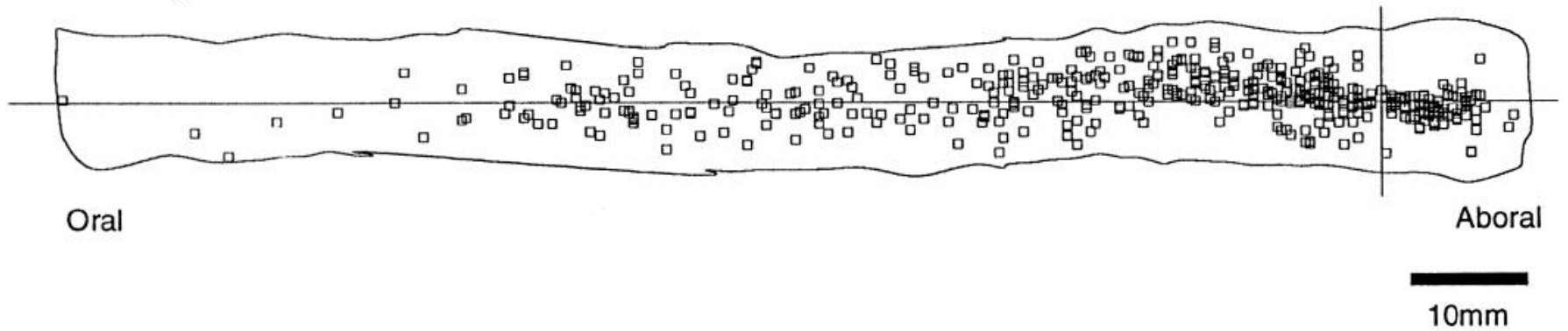

Figure 1. Distribution of Dogiel type II and other types of nerve cell bodies retrogradely labeled from a single internodal strand of the myenteric plexus at the origin of the axes. Each of the symbols represents a single, labeled nerve cell body. Calbindin-immunoreactive Dogiel type II nerve cell bodies are shown as a solid circle, Dogiel type II neurons lacking calbindin immunoreactivity as open circles and other types of cells as open squares. Nerve cell bodies were labeled up to $110 \mathrm{~mm}$ oral to the application site but only up to $13 \mathrm{~mm}$ aborally.
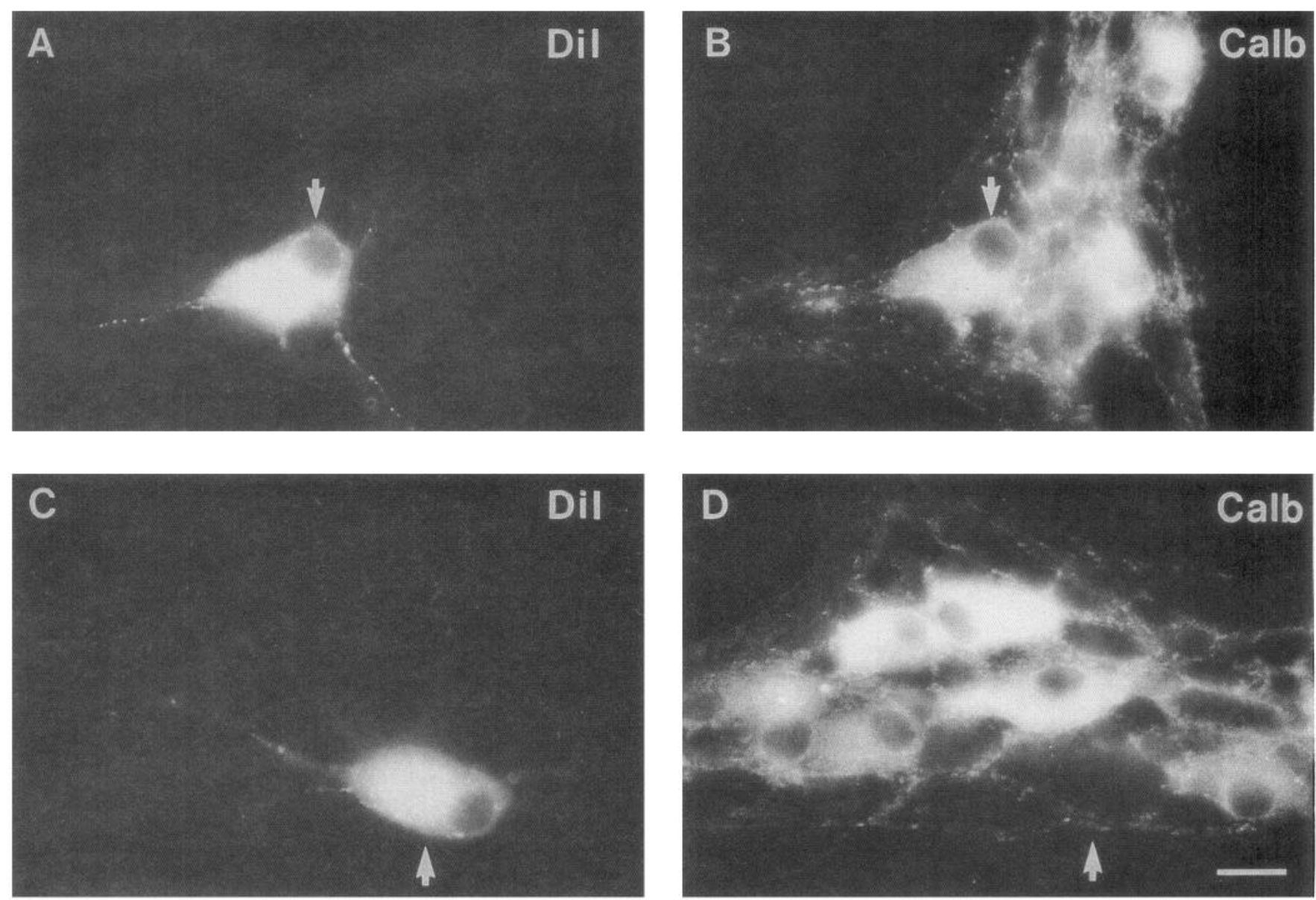

Figure 2. Calbindin immunoreactivity in DiI-labeled Dogiel type II neurons located $107 \mathrm{~mm}(A)$ and $90 \mathrm{~mm}(C)$ oral to a DiI application site (arrows) in the myenteric plexus. One neuron $(B)$ was immunoreactive for calbindin, the other was not $(D)$. Scale bar, $20 \mu \mathrm{m}$. 


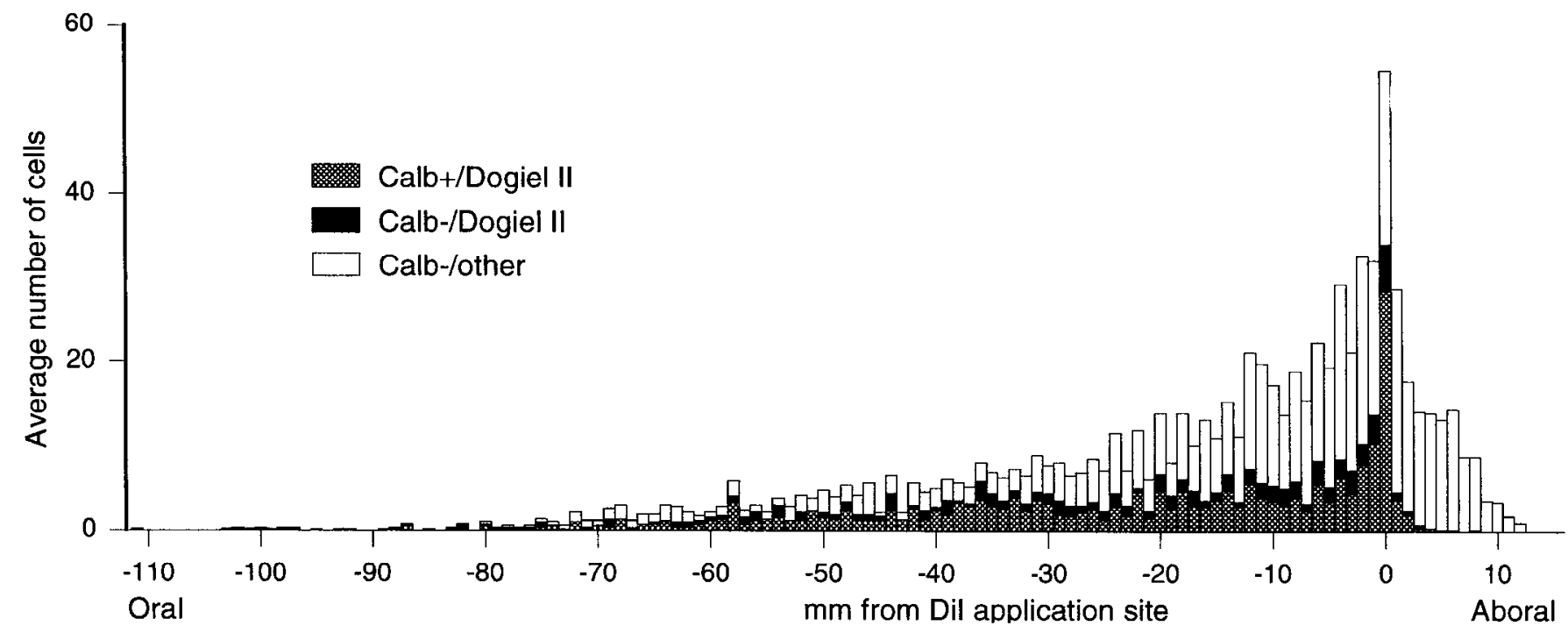

Figure 3. Distributions of Dogiel type II neurons, with and without calbindin immunoreactivity, retrogradely labeled from the myenteric plexus, shown as a stack histogram (five preparations). Many Dogiel type II neurons were located circumferential and within 2 mm longitudinally from the Dil application site. Dogiel type II neurons also comprised nearly $40 \%$ of all neurons labeled more than $2 \mathrm{~mm}$ oral to the application site and were found over $100 \mathrm{~mm}$ orally. Very few Dogiel type II neurons were labeled more than $2 \mathrm{~mm}$ aboral to the application site, indicating that they lack long orally projecting axons.

descending projections, DiI was applied to every internodal strand across the circumference of a preparation (from 20-28 application sites). The preparation was then labeled with calbindin antisera and the total number of calbindin-immunoreactive, DiI-labeled cells was counted in two separate sample areas, each $5 \mathrm{~mm}$ wide, located $10-15 \mathrm{~mm}$ and $40-45 \mathrm{~mm}$ oral to the application site. The number of calbindin-immunoreactive neurons within the same areas was also counted. Three preparations from three different animals were studied in this way. From 10-15 mm oral to the application sites, $10 \%$ of all calbindin-immunoreactive neurons were retrogradely labeled with DiI. Between $40-45 \mathrm{~mm}$ oral to the application site an average of $3 \%$ of calbindin-immunoreactive neurons were retrogradely labeled with Dil (see Table 1). These results indicate that a minimum of $10 \%$ of calbindin-immunoreactive neurons have aborally directed

Table 1. The minimum proportions of calbindin-immunoreactive neurons with aborally directed projections longer than $10 \mathrm{~mm}$ and $40 \mathrm{~mm}$ were calculated by applying DiI to every internodal strand across each of six preparations

\begin{tabular}{|c|c|c|c|c|c|c|c|c|}
\hline \multirow[b]{2}{*}{$\begin{array}{l}\text { Prep } \\
\#\end{array}$} & \multicolumn{4}{|c|}{$10-15 \mathrm{~mm}$} & \multicolumn{4}{|c|}{$40-45 \mathrm{~mm}$} \\
\hline & $\begin{array}{l}\text { Total } \\
\text { Calb }^{+} \\
\text {cells }\end{array}$ & $\begin{array}{l}\mathrm{DiI}^{+} \\
\text {Calb } \\
\text { cells }\end{array}$ & $\begin{array}{l}\% \\
+ \\
+ \\
\mathrm{Calb}^{+} \\
\mathrm{Dil}^{+}\end{array}$ & $\begin{array}{l}\mathrm{DiI}^{+} \\
\text {Do- } \\
\text { giel } \\
\text { II } \\
\text { Calb- }\end{array}$ & $\begin{array}{l}\text { Total } \\
\text { Calb }^{+} \\
\text {cells }\end{array}$ & $\begin{array}{l}\mathrm{Dil}^{+} \\
\text {Calb } \\
\text { cells }\end{array}$ & $\begin{array}{l}\% \\
+\mathrm{Calb}^{+} \\
\mathrm{DiI}^{+}\end{array}$ & $\begin{array}{l}\mathrm{DiI}^{+} \\
\text {Do-- } \\
\text { giel } \\
\text { II } \\
\text { Calb }^{-}\end{array}$ \\
\hline 1 & 1921 & 223 & $11.6 \%$ & 150 & 2127 & 77 & $3.6 \%$ & 29 \\
\hline 2 & 1781 & 220 & $12.3 \%$ & 150 & 1832 & 67 & $3.6 \%$ & 61 \\
\hline 3 & 1443 & 92 & $6.4 \%$ & 68 & 1526 & 32 & $2.1 \%$ & 42 \\
\hline Tota & & & $10.1 \%$ & & & & $3.1 \%$ & \\
\hline
\end{tabular}

The total number of calbindin-immunoreactive neurons between 10 and $15 \mathrm{~mm}$ oral to the application site, and the proportion of these that were labeled by DiI were determined. A1 least $10 \%$ of all calbindin-immunoreactive neurons have projections longer than $10 \mathrm{~mm}$ and at least $3 \%$ have projections longer than $40 \mathrm{~mm}$. In addition, many Dogiel type II neurons that lacked calbindin immunoreactivity were labeled in these areas. projections more than $10 \mathrm{~mm}$ long, and that at least $3 \%$ have projections more than $40 \mathrm{~mm}$ in length.

Observations of the morphology of the occasional neurons whose branching could be visualized, suggested that each cell gave rise to a single, aborally directed axon. In order to determine whether Dogiel type II neurons have more than one long aborally directed nerve fibre, or whether the long nerve fibers bifurcated and ran in more than one internodal strand, DiI was applied to five consecutive internodal strands and the number of calbindin-immunoreactive cells was compared to control preparations with a single DiI application site. The numbers of filled cells per bead did not differ significantly in the two types of preparations (see Table 2), indicating that calbindin-immuno-

\begin{tabular}{|c|c|c|}
\hline \multirow{2}{*}{$\begin{array}{l}\text { Distance } \\
\text { oral to DiI } \\
\text { application } \\
\text { site (mm) } \\
\end{array}$} & \multicolumn{2}{|c|}{ Labeled cells per bead } \\
\hline & $\begin{array}{l}\text { One-bead } \\
\text { preparation }\end{array}$ & $\begin{array}{l}\text { Five-bead } \\
\text { preparation }\end{array}$ \\
\hline 10 & $3.4 \pm 1.16$ & $3.25 \pm 0.75$ \\
\hline 20 & $4.4 \pm 1.12$ & $3.5 \pm 0.5$ \\
\hline 30 & $3.2 \pm 0.86$ & $2.55 \pm 0.05$ \\
\hline 40 & $2.4 \pm 0.68$ & $1.2 \pm 0.6$ \\
\hline 50 & $1.6 \pm 0.51$ & $1.2 \pm 0.2$ \\
\hline 60 & $1.4 \pm 0.68$ & $1.3 \pm 0.3$ \\
\hline 70 & $0.4 \pm 0.24$ & $0.55 \pm 0.25$ \\
\hline 80 & $0.6 \pm 0.24$ & $0.35 \pm 0.05$ \\
\hline
\end{tabular}

The results were expressed as the average numbers of labeled calbindin-immunoreactive neurons per bead (mean \pm SEM) in a band $1 \mathrm{~mm}$ wide across the circumference of the gut. If the axons of aborally projecting Dogiel type II neurons bifurcate within the myenteric plexus, this would be expected to reduce the number of filled cells per bead in preparations with five beads, since the same cell would have been filled from two Dil application sites. This did not occur, suggesting that most neurons of this class have a single aborally projecting axon that does not branch in multiple internodal strands. 

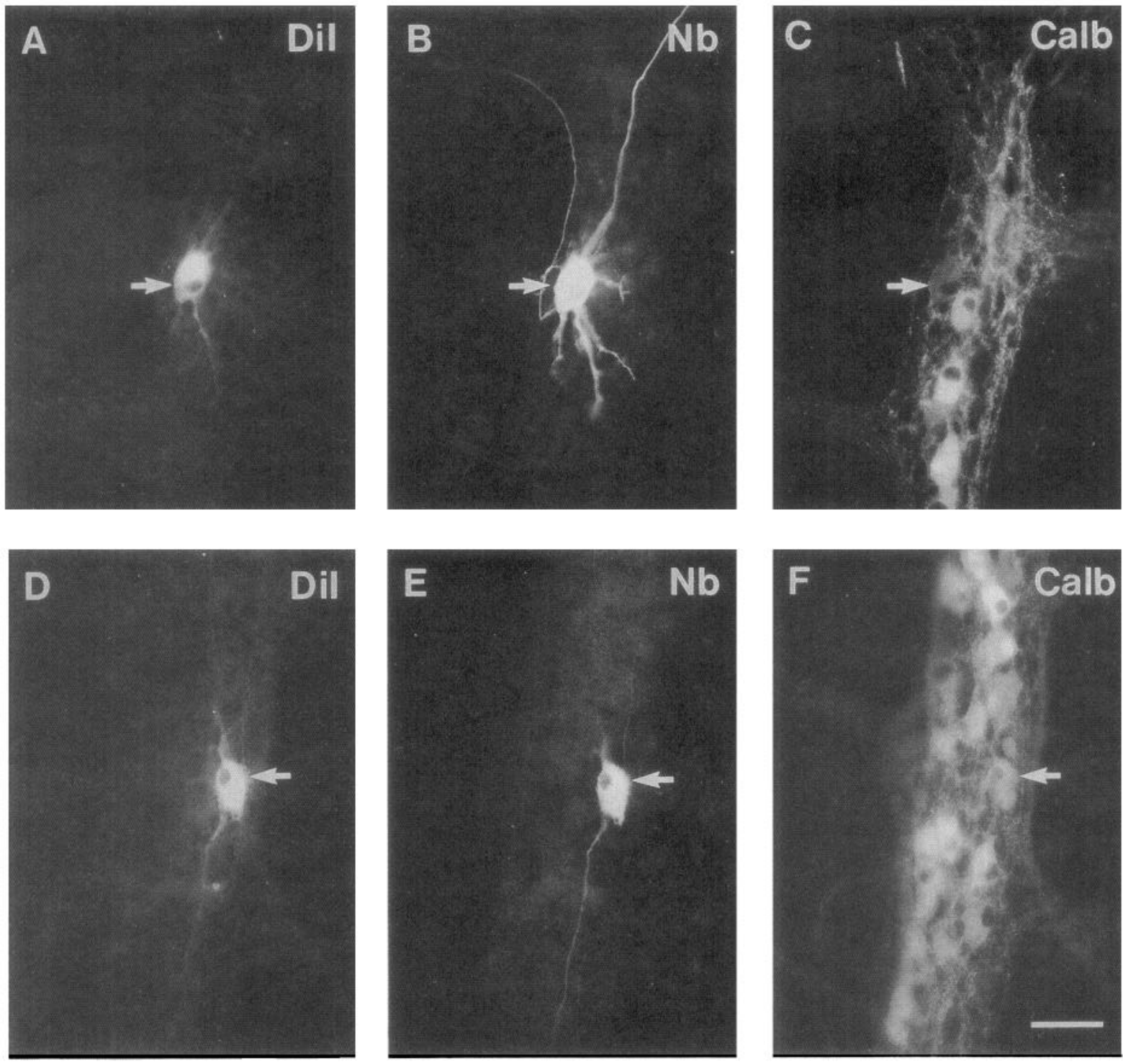

Figure 4. Detailed morphology and calbindin immunoreactivity of Dil-labeled Dogiel type II neurons located $16.4 \mathrm{~mm}(A-C)$ and $24.2 \mathrm{~mm}(D-$ $F$ ) oral to the DiI application site. DiI labeling revealed the basic Dogiel type II morphology with a large smooth cell body and several long tapering processes $(A, D)$. Intracellular injection of neurobiotin revealed the morphology in considerably more detail and revealed the presence in many cells, of short dendritic processes that were not always apparent with DiI labeling. One of the cells was immunoreactive for calbindin $(F)$ the other was not $(C)$, although faint bleed-through from the very intense neurobiotin labeling is visible. Scale bar, $100 \mu \mathrm{m}$.

reactive neurons usually give rise to a single long, descending axon that does not bifurcate.

\section{Morphological characteristics of Dogiel type II neurons with long descending projections}

Studies using intracellular dye injection and electrophysiological tracing methods have demonstrated that Dogiel type II neurons have a predominantly circumferential projection within the myenteric plexus; long, descending projections of these cells have not been previously reported. It was of interest then to determine whether the DiI-labeled neurons with long descending projections have typical Dogiel type II morphological characteristics. This was achieved by targeting DiI-labeled Dogiel type II neurons located more than $10 \mathrm{~mm}$ oral to the DiI application site for intracellular recording and dye filling with biocytin- or neurobiotin-containing microelectrodes.

Intracellular labeling with biocytin or neurobiotin revealed similar details of soma-dendritic morphology, but neurobiotin was preferred due to its greater solubility. Both labels showed considerably more of the detailed morphology than DiI alone (Fig. 4). Each neuron had a large, smooth, round to ovoid cell body that is typical of Dogiel type II neurons, averaging $44 \pm$ $4 \mu \mathrm{m}$ in length (mean \pm SEM; range, $28-69 \mu \mathrm{m}$ ) by $21 \pm 1$ $\mu \mathrm{m}$ in diameter (range, $15-30 \mu \mathrm{m} ; 11$ cells). The nucleus was asymmetrically located, usually toward the edges rather than the ends of the cell. Most of the intracellularly filled neurons had a number of short or "dendritic" processes arising from the cell body (average, $5 \pm 0.5$ dendrites; range, $2-8 ; 11$ cells). These were typically less than 1 cell body diameter in length and filamentous, often with side branches. Each cell body also gave rise to two or more long processes $(3 \pm 0.3$; range, $2-6 ; n=$ 20) that tapered and could then be traced for up to $4 \mathrm{~mm}$ circumferentially within the myenteric plexus. Typical examples of the soma-dendritic morphology of Dogiel type II neurons with 

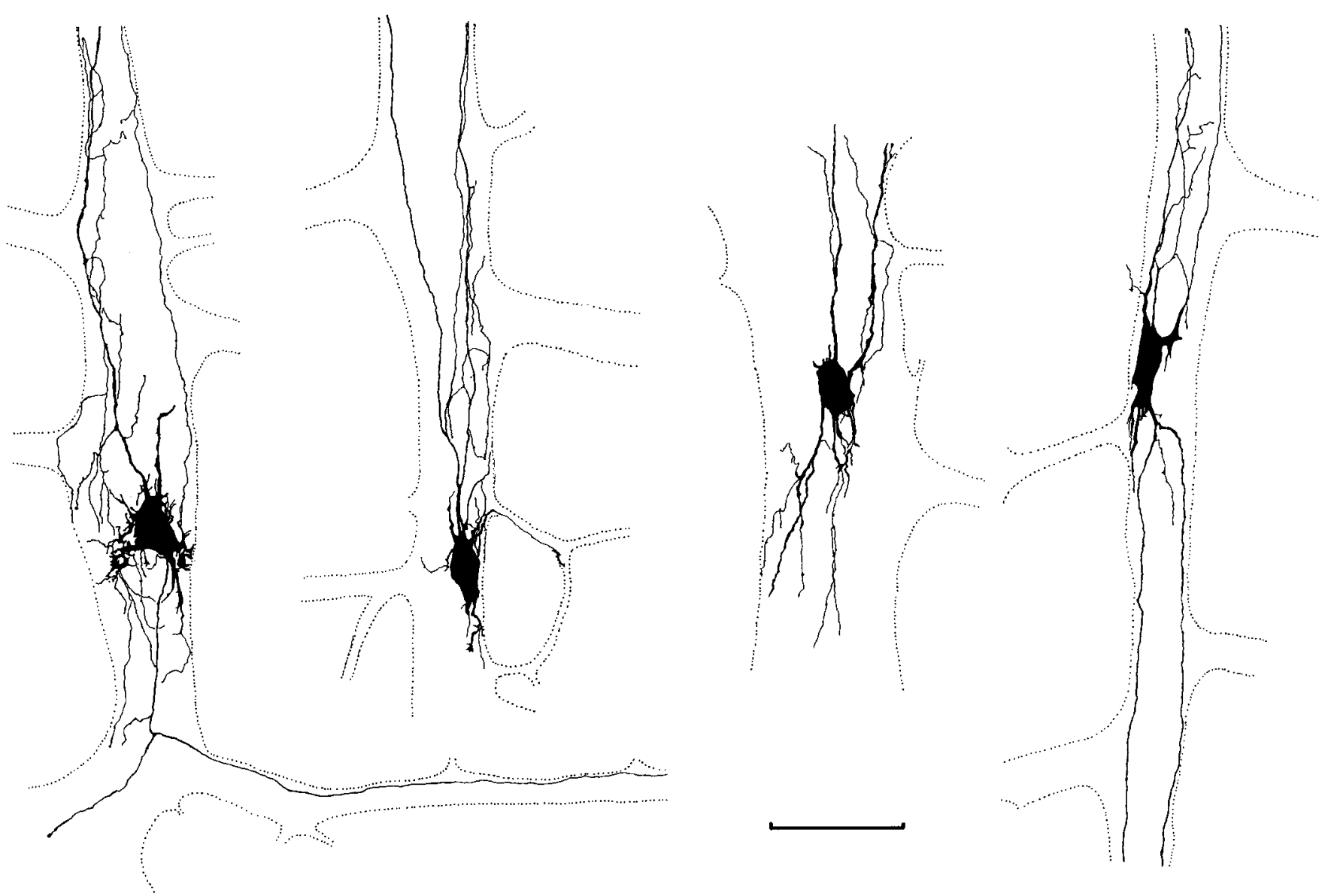

Figure 5. Camera lucida drawings of four neurobiotin-filled Dogiel type II neurons located $19.6 \mathrm{~mm}, 18.2 \mathrm{~mm}, 14 \mathrm{~mm}$, and $27.5 \mathrm{~mm}$ oral to the DiI application site (from the left). Note the relatively large cell bodies, with a predominantly ovoid shape. All of the cells had two or more long processes and variable numbers of short filamentous processes that are characteristic of "dendritic" Dogiel type II neurons. Oral is to the left. Scale bar, $100 \mu \mathrm{m}$.

long descending projections are shown in Figure 5. The long processes ran initially within myenteric ganglia, but often continued in circumferentially aligned secondary branches of the myenteric plexus. An example of the branching pattern of a Dogiel type II neuron with a long descending projection is shown in Figure 6. On many occasions the circumferentially running fibers entered and branched in other myenteric ganglia, suggesting that the secondary branches of the myenteric plexus are an important circumferential pathway within the wall of the small intestine.

Within myenteric ganglia, many long processes gave rise to narrow, varicose side branches that meandered and branched around other nerve cell bodies and probably represent the outputs of these neurons to other myenteric neurons (see Fig. 6). In two of the cells, one branch arising from a long process could be traced a short distance aborally within the myenteric plexus, before fading. Such polarized projections were only seen running in the aboral direction and may represent the long branch to the Dil application site, through which the cell body was originally labeled with Dil. Most of the long processes of these neurons, however, ended in retraction bulbs, usually at the severed ends of circumferentially aligned secondary branches of the myenteric plexus, presumably due to damage sustained during removal of the circular muscle, prior to recording. Retraction bulbs at these sites have becn suggested to be the points at which the nerve fibers project toward the mucosa (Bornstein et al.,
1991). On a number of occasions, retraction bulbs were seen emanating from the side of labeled nerve fibers which then continued within the secondary branch (Fig. 6) subsequently entering another myenteric ganglion. Thus, secondary branches probably have a dual role as both circumferential conduits between myenteric ganglia, and as part of the pathway between the myenteric plexus and the overlying layers of circular muscle, submucosa, and mucosa.

\section{Calbindin immunoreactivity of biocytin-labeled neurons}

Biocytin- or neurobiotin-labeled cells were visualized using either the blue fluorescence of AMCA or the greenish-yellow fluorescence of FITC-labeled streptavidin. Comparison with the red fluorescence of DiI was used to confirm that the correct cell had been impaled and recorded-cells in which this was not the case were discarded. In addition, tissue was processed for calbindin immunoreactivity. Of 12 neurons, 7 were immunoreactive for calbindin, the remainder were not. The calbindin-immunoreactive and non-immunoreactive neurons appeared indistinguishable on the basis of other morphological and electrophysiological features (see Fig. 5)

\section{Electrophysiological properties}

Intracellular recordings confirmed that the Dogiel type II neurons with long descending projections within the mycntcric plexus have the electrophysiological properties characteristic of $\mathrm{AH}$ 


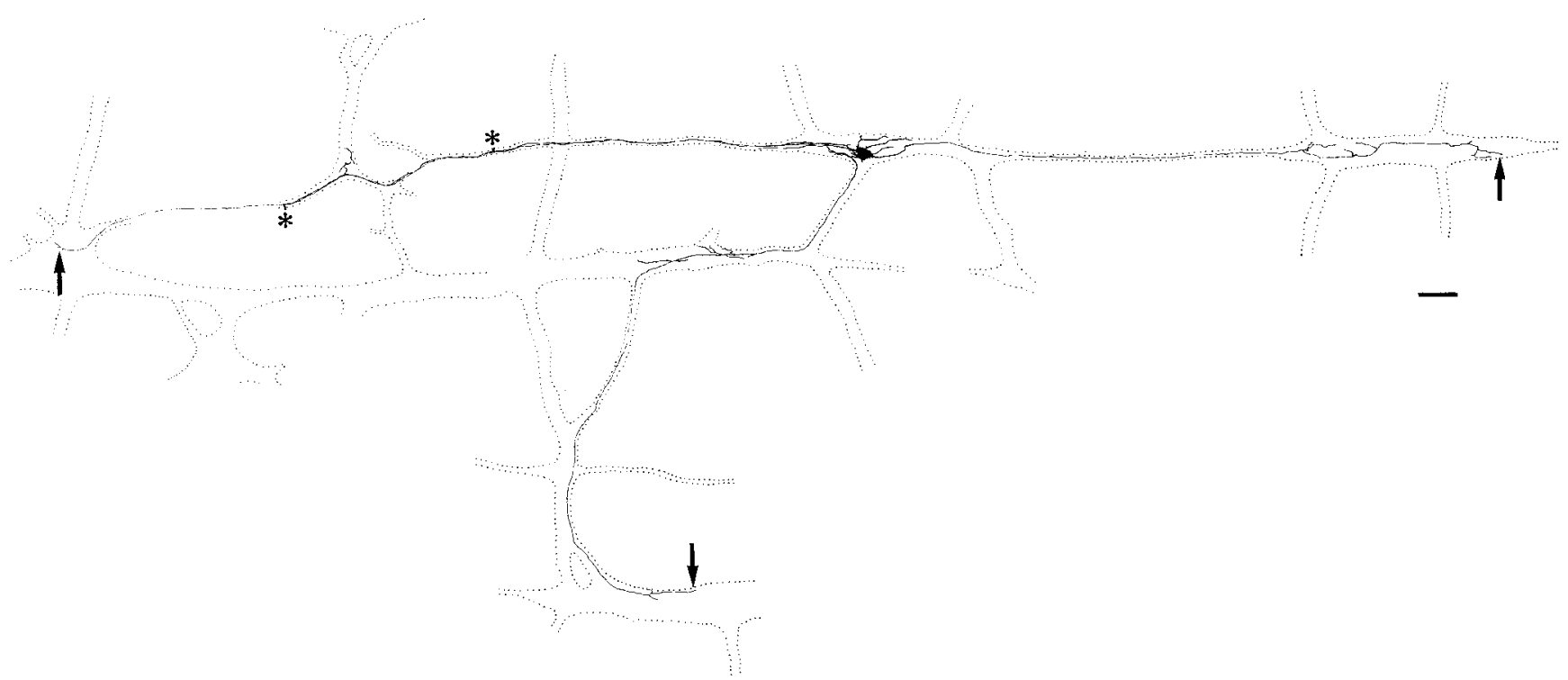

Figure 6. Camera lucida drawing of a neurobiotin-filled "dendritic" Dogiel type II neuron with its branching in the myenteric plexus. Four long processes originated from the cell bod;, three running circumferentially, one running aborally before fading (arrow). Two retraction bulbs were visible (asterisks), one at the severed end of an axon, the other apparently arising "en passant" from an axon that continued into the next ganglion. Fine varicose branches labeled with neurobiotin were visible in several of the ganglia through which axons passed. This neuron had an antidromic action potential from the DiI application site. Oral is toward the top. Scale bar, $200 \mu \mathrm{m}$.

cells. The neurons had relatively large resting potentials (average, $-64 \pm 2 \mathrm{mV}$; range, -57 to $-70 \mathrm{mV} ; 10$ cells) and intermediate input impedances (average, $143 \pm 11 \mathrm{M} \Omega$; rangc, 95-190 M $\mathrm{M}$ ). The cells responded to suprathreshold depolarizing current pulses by firing phasically at the onset of depolarization, from $1-9$ action potentials (average, $3 \pm 1$ action potentials; 9 cells) with maximum instantaneous firing frequencies of $40 \mathrm{~Hz}$ (average, $40 \pm 7 \mathrm{~Hz}$; range, 20-60 Hz; 6 cells). The soma action potentials were large in amplitude, usually overshooting $0 \mathrm{mV}$. Average amplitude was $71 \pm 4 \mathrm{mV}$ (7 cells). Action potentials typically had a relatively slow time course, with a pronounced inflection or "shoulder" on the falling phase (see Figs. 8, 10). Measured at half peak amplitude, the average duration was $2.7 \pm 0.2 \mathrm{msec}$ (range, $2.0-3.6 \mathrm{msec}$; $n=8$ cells). Action potentials were followed by a long, slow afterhyperpolarization, up to $10 \mathrm{mV}$ in amplitude and lasting up to $15 \mathrm{sec}$ (average, $7 \pm 2 \mathrm{mV}, 6 \pm 1 \mathrm{sec}$; 8 cells). Afterhyperpolarizations showed summation following repeated action potentials and were associated with a decrease in cell input im-

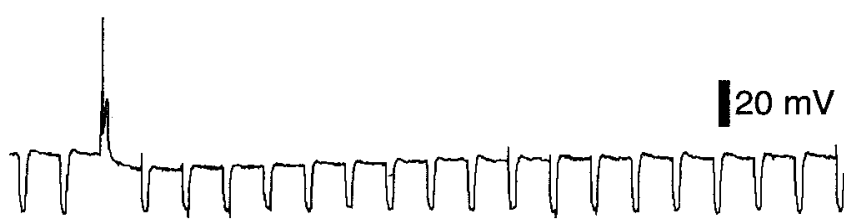

$0.5 \mathrm{nA}$

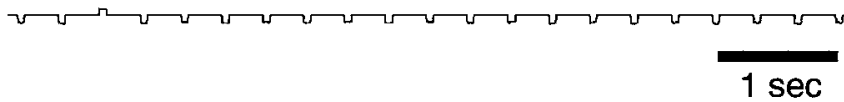

Figure 7. A depolarizing current pulse evoked a single action potential in a Dogiel type II neuron located $18.2 \mathrm{~mm}$ oral to the DiI application site. This was followed by a long afterhyperpolarization that is characteristic of $\mathrm{AH}$ cells, lasting about $4 \mathrm{sec}$. Membrane responses to constant current hyperpolarizing current pulses reveal an increase in conductance associated with the afterhyperpolarization. pedance, as measured by small, hyperpolarizing constant current pulses (Fig. 7). In response to hyperpolarizing constant current pulses, the cells typically responded with a hyperpolarization that tended to "sag" over the first $150 \mathrm{msec}$, before stabilizing. At the offset of the hyperpolarization, the membrane potential sometimes overshot the average resting potential, occasionally leading to action potential initiation. These types of responses have previously been characterized in $\mathrm{AH}$ cells and are due to a voltage dependent cation current, $I_{H}$ (Galligan et al., 1990) (Fig. 8). These features are characteristic of AH cells (Bornstein et al., 1994; Wood 1994)

Electrical stimulation within $1 \mathrm{~mm}$ circumferential of the recorded cell often evoked an antidromic action potential from a circumferentially running long process (Hendriks et al., 1990) that could be reduced in amplitude by hyperpolarizing the nerve cell body, leaving an electrotonically conducted axon spike with a rapid rise time $(<3.0 \mathrm{msec}$ to peak) and slower decay. With

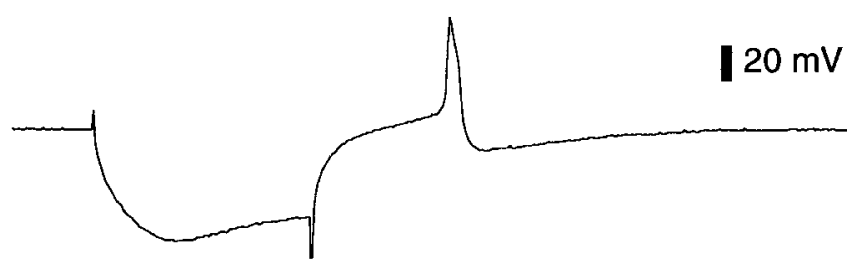

$0.5 \mathrm{nA}$

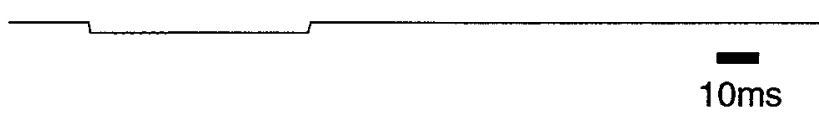

Figure 8. The membrane response to a hyperpolarizing current pulse shows a characteristic "sag" that has been shown in AH cells, to be caused by the cationic $I_{H}$ current. At the end of the hyperpolarizing current pulse, the membrane potential overshoots, leading to an action potential with a marked inflection on its falling phase. Recordings were from a Dogiel type II neuron located $12 \mathrm{~mm}$ oral to the DiI application site. 


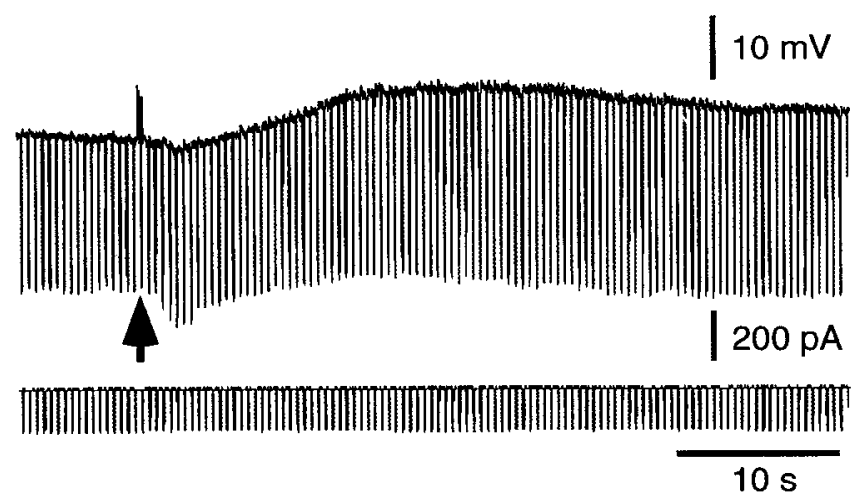

Figure 9. Focal electrical stimulation $(20 \mathrm{~Hz}, 0.5 \mathrm{sec}, 0.25 \mathrm{msec}$ pulses at the (arrow) approximately $1.5 \mathrm{~mm}$ from the recorded nerve cell body failed to evoke fast excitatory synaptic potentials in a Dogiel type II neuron located $15.3 \mathrm{~mm}$ oral to the DiI application site. However a slow excitatory synaptic potential was cvoked, lasting over $45 \mathrm{sec}$, associated with a decreased conductance (shown by the increase in the membrane response to constant current hyperpolarizing pulses).

increasing hyperpolarization, antidromic action potentials decreased in peak amplitude, or remained constant: they never showed the pronounced increase in amplitude that was typical of last excitatory postsynaptic potentials (fast EPSPs). In fact, none of the $\mathrm{AH}$ cells recorded in the present study received detectable fast EPSPs following electrical stimulation at any site in the preparation. With repetitive stimulation $1 \mathrm{~mm}$ circumferential to the recorded cell body (10-20 pulses per second, 0.25 msec duration, for $0.5-1 \mathrm{sec})$, slow EPSPs were evoked, although subsequent movement of the preparation often prematurely ended the recording. Slow excitatory postsynaptic potentials lasted from 30-120 sec, were associated with depolarization, increased input impedance, and increased excitability (see Fig. 9).

Previous studies have failed to demonstrate the existence of long descending projections from Dogiel type II neurons, using either morphological or electrophysiological techniques (Hendriks et al., 1990; Bornstein et al., 1991). It was of interest to determine whether the long, aborally directed processes from the cells in this study were capable of conducting action potentials. Focal electrical stimulation was applied near the DiI application site, since the cells must have projected to this point in order to have been retrogradely labeled. Twelve neurons located from 11.9 to $27.5 \mathrm{~mm}$ oral to the DiI application site were tested in this way. Five had antidromic action potentials from the DiI application site (see Fig. 10), with an average conduction velocity of $0.36 \pm 0.04 \mathrm{~m} / \mathrm{sec}$ (range, $0.25-0.47 \mathrm{~m} / \mathrm{sec} ; 5$ cells). The fact that seven neurons did not have intact projections to the application site was, at first sight, confusing. However, examination of the intracellular dye fills of these cells demonstrated that they had circumferential projections from their cell bodies that ended in retraction bulbs. This was presumably due to the severing of secondary branches of the myenteric plexus during the removal of the circular muscle layer prior to intracellular recording. It is probable that the long descending projections of these cells arose from nerve processes distal to the point of damage and hence were not detectable in electrophysiological preparations.

\section{Discussion}

This study has demonstrated that "dendritic" Dogiel type II neurons (Stach, 1989) in the myenteric plexus of the guinea-pig

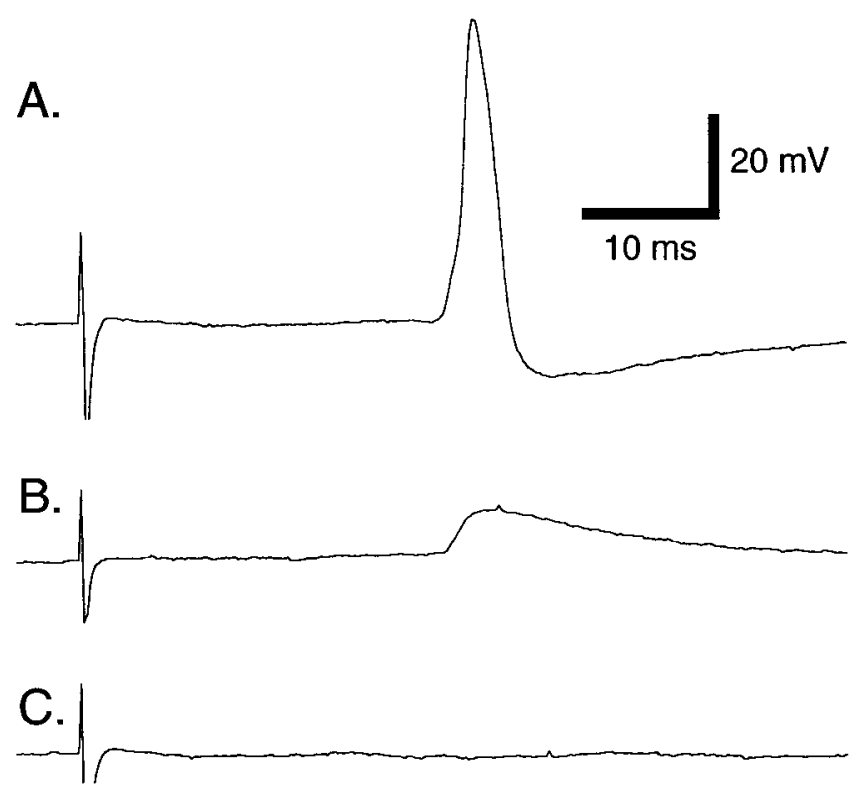

Figure 10. A, Antidromic action potential in a Dogiel type II neuron located $11.8 \mathrm{~mm}$ oral to the Dil application site. The latency of the action potential gives a calculated conduction velocity of $0.45 \mathrm{~m} / \mathrm{sec}$ by the long, aborally projecting nerve fiber. When the cell was hyperpolarized to $-99 \mathrm{mV}$, the soma action potential was blocked $(B)$ revealing a small axon spike with a rapid rise time and slow decay. Stimulation of an adjacent internodal strand $(C)$ near the DiI application site failed to evoke an antidromic event.

small intestine have long aboral projections that have not been reported previously. This type of enteric nerve cell forms a recognizable class of myenteric neurons with typical AH cell electrophysiological characteristics (see reviews by Bornstein et al. 1994; Wood 1994).

\section{Functional roles of "dendritic" Dogiel type II neurons}

"Dendritic" Dogiel type II neurons cannot be motor neurons since they are not retrogradely labeled from the circular or longitudinal muscle layers (Brookes and Costa, 1990; Brookes et al., 1991, 1992) and calbindin immunoreactivity, which is present in $70 \%$ of "dendritic" Dogiel type II neurons, is very sparse in the muscle layers (Furness et al., 1988, 1990). A recent study has demonstrated that all calbindin-immunoreactive Dogiel type II neurons can be retrogradely labeled from the mucosa (Song et al., 1994) and this must include the "dendritic" Dogiel type II neurons. Thus, "dendritic" Dogiel type II neurons are unlikely to be simple interneurons in the myenteric plexus.

Two other possibilities exist. "Dendritic" Dogiel type II neurons may be multifunctional neurons lacking fast excitatory synaptic inputs, but which receive slow synaptic inputs, which make outputs onto other myenteric neurons and have either inputs or outputs in the mucosa. Alternatively, "dendritic" Dogiel type II neurons may be a type of intrinsic sensory neuron. Enteric sensory neurons have never becn identificd directly duc to the difficulty of recording from a cell while mechanically stimulating the tissue, however, several lines of circumstantial evidence suggest that "dendritic" Dogiel type II neurons may have a sensory role.

First, the absence of fast excitatory synaptic potentials is compatible with a sensory role, since it suggests that the neurons are not directly synaplically driven by other presynaptic neurons (Hirst et al., 1974). However, these neurons do receive a slow 
excitatory synaptic input, sometimes sufficient to cause firing of action potentials: this may represent an interneuronal role for these cells, or may be a mechanism modulating their responsiveness to sensory stimuli. Slow excitatory synaptic inputs are likely to facilitate the transmission of action potentials across the nerve cell body of multipolar (Dogiel type II) enteric neurons (Wood, 1989). The presence of slow synaptic excitation could determine how many of the other axons would be invaded by an incoming action potential generated remotely in a single axon, perhaps in the mucosa. Recordings from pairs of myenteric neurons have recently revealed that the varicose endings arising from the axons of Dogiel type II neurons make synaptic outputs onto other neurons (Kunze et al., 1993).

A second piece of circumstantial evidence supporting a sensory role for "dendritic" Dogicl type II ncurons is the projection of these cells to the mucosa, since mucosal stimulation can evoke polarized motor reflexes in the small intestine (Hukuhara et al., 1958; Smith and Furness, 1988), even in the absence of extrinsic nerve fibers (Furness et al., 1994). Five classes of enteric neurons can be retrogradely labeled from the mucosa (Song et al., 1991, 1992) and can be distinguished by the presence of VIP, NPY or calretinin immunoreactivities or Dogiel type II morphology (in either submucous or myenteric neurons). It would be expected that enteric sensory neurons sensitive to mucosal stimuli would have sensory endings in the mucosa and outputs in either submucous or myenteric ganglia. Of the five classes of neurons that project to the mucosa, only the Dogiel type II neurons (in both the submucous and myenteric plexuses) have been demonstrated to have such a dual projection. The VIP-, NPY- and calretinin-immunoreactive nerve endings in mycnteric and submucous ganglia appcar to originate from myenteric interneurons that project up or down the gut (Costa and Furness, 1983; Furness et al., 1983: Brookes et al., 1991) whereas submucous and myenteric Dogiel type II neurons have both been demonstrated to give rise to projections into enteric ganglia (Kirschgessner and Gershon, 1988; Bornstein et al, 1991) and to project to the mucosa (Song et al., 1994). It is likely, therelore, that enteric sensor y neurons to the mucosa have Dogiel type II morphology and must include the "dendritic" neurons of the present study.

Third, "dendritic" Dogiel type II neurons have a striking similarity to a class of submucous neurons, immunoreactive for substance $P$, that have previously been suggested to be intrinsic sensory neurons (Bornstein et al., 1989; Kirschgessner et al. 1992). These cells express Fos immunoreactivity following mucosal stimulation (Kirschgessner et al., 1992) even when fast excitatory synaptic transmission is blocked with hexamethonium. They are similar to Dogiel type Il neurons in the myenteric plexus, having relatively few fast excitatory synaptic inputs, a long afterhyperpolarization following action potentials and slow synaptic inputs (Bornstein et al., 1989). These neurons are also multipolar (Bornstein et al., 1989) project both to the mucosa (Song et al., 1992) and myenteric plexus (Kirschgessner and Gershon 1988), and some are immunoreactive for calbindin (Kirschgessner and Gershon, 1988; Kirschyessner et al., 1992). "Dendritic" Dogiel type II neurons share these characteristics and thus may also have a sensory role in the intestine.

It has been proposed, using similar arguments, that all Dogiel type II neurons, with AH cell electrophysiological features, are likely to be intrinsic sensory neurons in the guinea pig small intestine (Furness et al., 1988) suggesting that there may be two classes of enteric sensory neurons (i.e., "dendritic" and "non- dendritic"). Evidence for two functional classes of enteric sensory neurons has been provided by the analysis of interactions between motor reflexes evoked by mucosal stimulation and by distension (Smith et al., 1991). Since both "dendritic" and "nondendritic" Dogiel type II neurons project to the mucosa (Song et al., 1994), it seems unlikely that one class is a distension receptor and the other a mucosal receptor. A recent study in the rat colon has provided evidence that reflexes evoked by mucosal stimulation are mediated by intrinsic sensory neurons, whereas reflexes evoked by distension can be blocked by interrupting extrinsic neuronal pathways to the gut (Grider and Jin, 1994). This suggests that, at least in this preparation, distensionevoked reflexes may be mediated by the peripheral axons of extrinsic sensory neurons. The nature of the difference in function betwecn "dendritic" and "nondendritic" Dogiel type II neurons in the guinea pig small intestine thus remains to be determined. It should also be pointed out, however. that there is currently some debate as to whether Dogiel type II neurons are indeed sensory, or whether they may have a primarily interneuronal role (Wood, 1994).

The failure of Bornstein et al., (1991) to identify the long descending projection of "dendritic" Dogiel type II neurons by intracellular dye filling was probably due to the damage caused to the preparation by the removal of the circular muscle layer just prior to recording. The long, aborally directed nerve fibre usually arises from a circumferentially directed axon, often at some distance from the cell body. Thus, damage to a circumferential axon may also disrupt the long descending projections. This is also the simplest explanation for the observation that 7 out of 12 "dendritic" Dogiel type II neurons in the present study did not have intact projections to the DiI application site at the time of recording, even though they had been retrogradely labeled prior to removal of the circular muscle layer.

\section{Quantitation of "dendritic" Dogiel type II neurons}

The subtype of Dogiel type II neurons with long, aborally directed projections and "dendritic" morphology account for about $10 \%$ of all Dogiel type II neurons, based on the proportion of all calbindin neurons that can be labeled with Dil applied 10 $\mathrm{mm}$ aborally. Bornstein et al. (1992) found a similar proportion of randomly impaled Dogiel type II neurons were of the "dendritic" type. Calbindin-immunoreactive neurons account for 22$28 \%$ of myenteric neurons (Furness et al., 1990; Young et al., 1993). From 15-30\% of Dogiel type II neurons lack calbindin immunoreactivity (Iyer et al., 1988; Song et al., 1991; this study), thus Dogiel type II neurons account for $25-39 \%$ of all myenteric neurons. "Dendritic" Dogiel type II neurons must comprise $3-4 \%$ of all myenteric neurons, but account for $43 \%$ of all neurons labeled more than $2 \mathrm{~mm}$ oral to a DiI application site. This discrepancy is most simply explained by the very long projections of many of these neurons, which would increase their probability of filling compared to other neurons with shorter projections. The other major classes of neurons with long aboral projections in the myenteric plexus are defined by the presence of vasoactive intestinal polypeptide (Costa and Furness, 1983), 5-hydroxytryptamine (Furness and Costa, 1982) or somatostatin (Costa et al., 1980). "Dendritic" Dogiel type II neurons, which are not immunoreactive for any of these substances, form the largest single aboral projection.

The results of the present study have revealed a marked asymmetry in the length of orally and aborally projecting neurons with oral projections up to $13 \mathrm{~mm}$ long, and aboral projections 
up to $100 \mathrm{~mm}$. The "dendritic" type Il neurons have amongst the longest projections of any of these neurons. If they are indeed sensory neurons, localized stimulation may lcad to synaptic outputs to myenteric neurons along a considerable length of the intestine aborally, possibly without interneuronal pathways being activated. The length and polarity of the projections of "dendritic" Dogiel type II neurons suggest that they are likely to play an important role in aborally directed reflexes in the intestine.

\section{References}

Bornstein JC, Costa M, Furness JB, Lees GM (1984) Electrophysiol ogy and enkephalin immunoreactivity of identified myenteric plexus neurons of guinea-pig small intestine. J Physiol (Lond) 351:313-325.

Bornstein JC, Furness JB, Costa M (1989) An electrophysiological comparison of substance $\mathrm{P}$-immunoreactive neurons with other neurons in the guinea-pig submucous plexus. J Auton Nerv Syst 26:113120

Bornstein JC, Hendriks R, Furness JB, Trussell DC (1991) Ramifications of the axons of AH-neurons injected with the intracellular marker biocytin in the myenteric plexus of the guinea-pig small intestine. J Comp Neurol 314:437-451.

Bornstein JC, Kunze WAA, Furness JB (1992) Calbindin immunoreactivity in morphologically distinct classes of putative enteric sensory neurons in guinea-pig ileum. Proc Aust Physiol Pharmacol Soc 23:44P.

Bornstein JC, Furness JB, Kunze WAA (1994) Electrophysiological characterization of myenteric neurons: how do classification schemes relate? J Auton Nerv Syst 48:1-15.

Brookes SJH, Costa M (1990) Identification of enteric motor neurons which innervate the circular muscle of the guinea-pig small intestine. Neurosci Lett 118:227-230.

Brookes SJH, Steele PA, Costa M (1991) Identification and immunohistochemistry of cholinergic, non-cholinergic circular muscle motor neurons in the guinea-pig small intestine. Neuroscience 42:863-878.

Brookes SJH, Altree-Williams J, Costa M (1992a) A computerised mapping system for fluorescence microscopy. Proc Aust Neurosci Soc $3: 205$

Brookes SJH, Song Z-M, Steele PA, Costa M (1992b) Identification of motor ncurons to the longitudinal muscle of the guinea-pig ileum. Gastroenterology 103:961-973.

Celio MR, Norman AW (1985) Nucleus basalis of Meynert contain calbindin D 28k. Anat Embryol 173:143-148.

Christofi FL, Wood JD (1993) Effects of PACAP on morphologically identified myenteric neurons in guinea pig small bowel. Am J Physiol 264:G414-G421.

Costa M, Furness JB (1983) The origins, pathways and terminations of neurons with VIP-like immunoreactivity in the guinea-pig small intestine. Neuroscience 8:665-676.

Costa M, Furness JB, Llewellyn-Smith IJ, Davies B, Oliver J (1980) An immunohistochemical study of the projections of somatostatincontaining neurons in the guinea-pig small intestine. Neuroscience $5: 841-852$

Erde SM, Sherman D, Gershon MD (1985) Morphology and serotonergic innervation of physiologically identified cells of the guineapig's myenteric plexus. J Neurosei 5:617-633.

Furness JB, Cosla M (1982) Neurons with 5-hydroxytryptamine-like immunoreactivity in the enteric nervous system: their projections in the guinea-pig small intestine. Neuroscience 7:341-349.

Furness JB, Costa M, Emson PC, Hakanson R, Moghimzadeh E, Sundler F, Taylor IL, Chance RE (1983) Distribution, pathways and reactions to drug treatment of nerves with neuropeptide- $Y$ and pancreatic polypeptide-like immunoreactivity in the guinea-pig digestive tract. Cell Tissue Res 234:71-92.

Furness JR, Costa M, Keast JR (1984) Choline acetyltransferase and peptide immunoreactivity of submucous neurons in the small intestine of the guinea-pig. Cell Tissue Res 250:607-615

Furness JB, Keast JR, Pompolo S, Bornstein JC, Costa M, Emson PC, Lawson DEM (1988a) Immunohistochemical evidence for the presence of calcium-binding proteins in enteric neurons. Cell Tissue Res 252:79-87

Furness JB, Llewellyn Smith IJ, Bornstein JC, Costa M (1988b) Chem- ical neuroanatomy and the analysis of neuronal circuitry in the enteric nervous system. In: Handbook of chemical neuroanatomy (Owman C, Bjorklund A, Hokfelt T, eds). Amsterdam: Elsevier.

Furness JB, Pompolo S, Murphy R, Giraud A (1989) Projections of neurons with neuromedin U-like immunoreactivity in the small intestine of the guinea-pig. Cell Tissue Res 257:415-422.

Furness JB, Trussell DC, Pompolo S, Bornstein JC, Smith TK (1990) Calbindin neurons of the guinea-pig small intestine: quantitative analysis of their numbers and projections. Cell Tissue Res 260:261-272.

Furness JB, Johnson P, Pompolo S, Bornstein JC (1994) Enteric reflexes in the small intestine after degeneration of extrinsic and long intramural nerve pathways. Proc $\Lambda$ ust Neurosci Soc 5:51.

Galligan JJ, Tatsumi H, Shen K-Z, Surprenant A, North RA (1990) Cation current activated by hyperpolarization $\left(I_{I \prime}\right)$ in guinea-pig enteric neurons. An J Physiol 259:G966-G972.

Grider JR, Jin JG (1994) Distinct populations of sensory neurons mediate the peristaltic reflex elicited by muscle stretch and mucosal stimulation. J Neurosci 14:2854-2860.

Hendriks R, Bornstein JC, Furness JB (1990) An electrophysiological study of the projections of putative sensory neurons within the myenteric plexus of the guinea-pig ileum. Neurosci Lett 110:286-290.

Hirst GDS, Holman ME, Spence I (1974) Two types of neurons in the myenteric plexus of duodenum in the guinea-pig. J Physiol (I ond) 236:303-326

Hukuhara E, Yamagami M, Nakayama S (1958) On the intestinal reflexes. Jpn J Physiol 8:9-20.

Iyer V, Bornstein JC, Costa M, Furness JB, Takahashi Y, Iwanaga T (1988) Electrophysiology of guinea-pig myenteric neurons correlated with immunoreactivity for calcium binding proteins. J Auton Nerv Syst 22:141-150.

Katayama Y, Lees GM, Pearson GT (1986) Electrophysiology and morphology of vasoactive intestinal peptide immunoreactive neurons of the guinea-pig ileum. J Physiol (Lond) 378:1-11.

Kirchgessner AL, Gershon MD (1988) Projections of submucosal neurons to the myenteric plexus of the guinea-pig intestine: in vitro tracing of microcircuits by retrograde and anterograde transport. J Comp Neurol $277 \cdot 487-498$

Kirchgessner AL, Tamir H, Gershon MD (1992) Identification and stimulation by serotonin of intrinsic sensory neurons of the submucosal plexus of the guinea pig gut: activity-induced expression of Fos immunoreactivity. J Neurosci 12:235-248.

Kunze WAA, Furness JB, Bornstein JC (1993) Simultaneous intracellular recordings from enteric neurons reveal that mitenteric $\mathrm{AH}$ cells transmit via slow excitatory post synaptic potentials. Neuroscience 55:685-694

Smith TK, Furness JB (1988) Reflex changes in circular muscle activity elicited by stroking the mucosa: an electrophysiological analysis in the isolated guinea-pig ileum. J Auton Nerv Syst 25:205-218.

Smith TK, Bornstein JC, Furness JB (1991) Interactions between reflexes evoked by distension and mucosal stimulation: electrophysiological studies of guinea-pig ileum. J Auton Nerv Syst 34:69-76.

Song Z-M, Brookes SJH, Costa M (1991) Identification of myenteric neurons which project to the mucosa of the guinea-pig small intestine. Neurosci Lett 129:294 298.

Song Z-M, Brookes SJH, Steele PA, Costa M (1992) Projections and pathways of submucous neurons to the mucosa of the guinea-pig small intestine. Cell Tissue Res 269:87-98.

Song Z-M, Brookes SJH, Costa M (1994) All calbindin-immunoreactive myenteric neurons project to the mucosa of the guinea-pig small intestine. Neurosci Lett 180:219-222.

Stach W (1989) A revised morphological classification of neurons in the enteric nervous system. In: Nerves and the gastrointestinal tract (Singer MV, Goebell H, eds), pp 29-45. Lancaster, UK: Kluwer.

Steele PA, Brookes SJH, Costa M (1991) Immunohistochemical identification of cholinergic neurons in the myenteric plexus of guineapig small intestine. Neuroscience 45:227-239.

Wood JD (1989) Electrical and synaptic behaviour of enteric neurons In: Handbook of physiology, Sec 6, The gastrointestinal system, Vol 1, Pt 1 (Schultz SG, Wood JD, eds). Bethesda, MD: American Physiological Society.

Wood JD (1994) $\Lambda$ pplication of classification schemes to the enteric nervous system. J Auton Nerv Syst 48:17-29.

Young HM, Furness JB, Sewell P, Burcher EF, Kandiah CJ (1993) Total numbers of neurons in myenteric ganglia of the guinea-pig small intestine. Cell Tissue Res 272:197-200. 